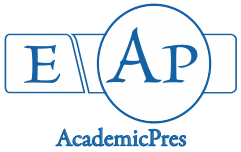

AcademicPres

Obisesan IA et al. (2021)

Notulae Scientia Biologicae 13(1):10844

DOI: $10.15835 /$ nsb13110844

Research Article

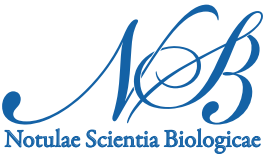

\title{
Explants selection for in vitro propagation of Pachyrhizus erosus $\mathrm{L}$.
}

\author{
Idowu A. OBISESAN ${ }^{1 *}$, Ayobola M.A. SAKPERE ${ }^{2}$, \\ Bamidele J. AMUJOYEGBE ${ }^{3}$, Michael S. AKINROPO \\ ${ }^{1}$ Bowen University Iwo, College of Agriculture, Engineering and Sciences, Pure and Applied Biology, Osun State, Nigeria; \\ idowu.obisesan@bowen.edu.ng (*corresponding author) \\ ${ }^{2}$ Obafemi Awolowo University, Faculty of Science, Department of Botany, Ile-Ife, Osun State, Nigeria; aasakpere@oauife.edu.ng \\ ${ }^{3}$ Obafemi Awolowo University, Faculty of Agriculture, Department of Crop production and Protection, Ile-Ife, Osun State, \\ Nigeria;bamujo@oauife.edu.ng
}

\begin{abstract}
Pachyrhizus erosus tuber is rich in protein asides its agronomical value as a legume, but the seeds by which it is propagated have very low viability. This study established sterilization protocol and effect of various concentrations of auxins and cytokinins on callus production and shoot regeneration from explants of $P$. erosus. Explants and seeds were sterilized using sodiumhypochlorite $(\mathrm{NaClO})$ solution $(5,10$ and $15 \% \mathrm{v} / \mathrm{v})$ for 5 and 10 mins. Nodal, stem and leaf explants from in vitro germinated P. erosus and tuber from field grown plant were sterilized and cultured on Murashige and Skoog (MS) medium (control) and MS combined with different concentrations of auxins (NAA and 2, 4-D) and cytokinin (BA and Kinetin) and the cultured explants were monitored in terms of degree of callus formation, morphology and colour of callus and also for shoot induction. The results showed that seeds of $P$. erosus sterilized with $10 \% \mathrm{NaClO}$ solution for 10 mins and germinated in vitro is the best way of getting sterile nodal, stem and leaf explants for the in vitro propagation of the plant, while tuber explants could be sterilized with $15 \% \mathrm{NaClO}$ for 10 minutes. Nodal explants inoculated in MS medium supplemented with $1.0 \mathrm{mg} / \mathrm{L} \mathrm{BA}$ gave the highest shoot regeneration response, while stem explants inoculated on MS medium supplemented with $1.0 \mathrm{mg} / \mathrm{L} \mathrm{BA}$ and $0.5 \mathrm{mg} / \mathrm{L} \mathrm{NAA}$ also gave the highest amount of friable callus. The study concluded that in vitro germinated seeds were the best way of getting explant for P. erosus.
\end{abstract}

Keywords: auxins; callus; contamination; cytokinins; legume; Pachyrhizus erosus; shoot regeneration

\section{Introduction}

Food security, protein malnutrition, increasing population, uncertain crop yield and high cost of animalbased protein food supplies in developing countries have created an urge to identify and incorporate unconventional protein source to supplement indigenous crop (Masood and Rizwana, 2010). Diversifying diets with legumes are a cheaper and more sustainable way to supply a range of nutrients to the body and combat malnutrition. Therefore, the need for innovative legume research solutions to improve food and nutritional security cannot be overemphasized (Ojiewo et al., 2015).

Received: 03 Nov 2020. Received in revised form: 06 Jan 2021. Accepted: 15 Jan 2021. Published online: 21 Jan 2020.

From Volume 13, Issue 1, 2021, Notulae Scientia Biologicae journal will use article numbers in place of the traditional method of continuous pagination through the volume. 
Pachyrhizus erosus commonly called Mexican yam bean is an important legume with high nutritional value. Its tubers contain higher protein than most African indigenous tubers (Santos et al., 1996; Bergthaller et al., 2001; Slavin, 2005; Padonou, 2013). Propagation of P. erosus is by seeds which are known to have rapid decrease in germination after 4 hours and remained viable for only 22 hours (Sorensen, 1996), giving rise to decreasing seed viability during storage. An alternative means of propagation for mass cultivation therefore necessitate its micropropagation. In vitro plant tissue culture has been reported to be a good alternative for the propagation and conservation of economic legumes. For instance, Singh et al. (2019) established a protocol for in vitro propagation of the wild legume Cicer microphyllum. Shahinozzaman et al. (2012) established a protocol for in vitro clonal propagation of Acacia mangium using seedling derived explants.

Explants contamination is one of the major problems encountered during propagation of plants in vitro, especially from underground organs (such as tubers), which has been in contact with debris and soil microorganisms (Cassells, 1991; Omamor et al., 2007; Singh et al., 2011). Varying the concentration of sterilant and duration of contact of explants with sterilants has been in practice amongst in vitro researches (Niedz et al., 2002; Mahna et al., 2013). Determining the best explants for callus formation and multiple shoot regeneration is important in establishing a protocol for micropropagation of the plant.

The objective of this study was to investigate the best sterilization method for in vitro propagation of $P$. erosus, to determine the best explants for in vitro propagation of the plant; and study the effect of different concentrations of hormones on regeneration ability and callus formation in the plant.

The study provides information on the micropropagation of $P$. erosus as an alternative method to mitigate the effect of loss of seed viability and for rapid multiplication of the plant as well as for possible future genetic modification of $P$. erosus.

\section{Materials and Methods}

\section{Media preparations and culture conditions}

Murashige and Skoog (1962) (MS) media was used for the study. This was supplemented with $7.5 \mathrm{~g}$ sucrose, $0.025 \mathrm{~g}$ myo-inositol, $0.0093 \mathrm{~g}$ EDTA, $0.0069 \mathrm{~g} \mathrm{Fe}$, and made up to mark with distilled water (Sathyanarayana and Verghese, 2007). The solution was poured into a beaker and the $\mathrm{pH}$ adjusted to $5.7 \pm 0.2$ with $0.1 \mathrm{~N}$ (Normal) $\mathrm{HCl}$ and/or $0.1 \mathrm{~N} \mathrm{NaOH}$ before adding 0.5 g phytagel as the gelling agent. The medium was thereafter heated on a hot plate while mixing with a magnetic stirrer until it boiled, after which $5 \mathrm{ml}$ each of the medium was dispensed into $50 \mathrm{ml}$ test tubes. The test tubes were covered with cotton-wool, wrapped with parafilm and autoclaved for 15 minutes (min) at $121^{\circ} \mathrm{C}$ and $108 \mathrm{~K} \mathrm{~Pa}$.

\section{Surface sterilization procedure for explants}

Four weeks old stem, node, leaf and 12 weeks old tuber collected from screen house were used as sources of explants. Five replicates were used for each explant and the experiment carried out twice. Sterilant (Chlorox (C) which contains $8.25 \% \mathrm{NaClO}$ solution was used at $5 \% \mathrm{v} / \mathrm{v}, 10 \% \mathrm{v} / \mathrm{v}$ and $15 \% \mathrm{v} / \mathrm{v}$ for $5 \mathrm{~min}$ and $10 \mathrm{~min}$ each respectively.

Explants were cut into approximately $1 \mathrm{~cm}$ each and were washed with liquid soap and rinsed under running tap for $30 \mathrm{~min}$. The explants were transferred under a Laminar Flow Hood (under sterile condition) into $70 \%$ ethanol for $5 \mathrm{~min}$. The ethanol was decanted and the explants further sterilized in $\mathrm{NaClO}$ solution for the different specified percentages and durations earlier mentioned, with 2 drops of Tween 20 added. After sterilization, the explants were rinsed with sterile distilled water thrice. The explants were cultured in $5 \mathrm{ml} \mathrm{MS}$ media in $50 \mathrm{ml}$ capacity test tubes and then transferred to the growth room maintained at $25^{\circ} \mathrm{C} \pm 2{ }^{\circ} \mathrm{C}$ and 16 hours light and 8 hours darkness photoperiod.

Sixty P. erosus seeds were soaked for 9 hours (over-night) to soften the testa. Seed testa were removed with the aid of forceps, the cotyledon and intact embryo washed with liquid soap and rinsed under running 
water for $15 \mathrm{~min}$. These were transferred into $250 \mathrm{ml}$ of $70 \%$ ethanol for 5 minutes in a Laminar Flow Hood. After decanting the ethanol, the seeds were transferred into $\mathrm{NaClO}$ solution with two drops of Tween 20 for the different specified percentages and durations mentioned above. Thereafter, seeds were rinsed thrice with sterile distilled water before inoculation into $5 \mathrm{ml}$ of MS media in test tubes.

Direct regeneration and callus initiation from P. erosus explants

Different concentrations of plant growth regulator (Table 1) were supplemented in MS medium and tested for their effects on callus induction and shoot regeneration from explants of field grown tuber, and also from nodal, leaf and stem explants excised from in vitro germinated seedlings. Explants were cultured on MS medium alone as control (Treatment 1); five explants were used per treatment. The experiment was carried out twice and was observed within the period of 4 weeks.

Table 1. Concentrations and combinations of BA, NAA, kinetin and 2,4-D used as supplements in MS medium for investigating callus induction and shoot regeneration from $P$. erosus explants

\begin{tabular}{|c|c|c|c|c|}
\hline Treatment & BA $(\mathrm{mg} / \mathrm{L})$ & NAA $(\mathrm{mg} / \mathrm{L})$ & Kinetin $(\mathrm{mg} / \mathrm{L})$ & $2,4-\mathrm{D}(\mathrm{mg} / \mathrm{L})$ \\
\hline 1 & - & - & - & - \\
\hline 2 & 1.0 & - & - & - \\
\hline 3 & 1.0 & 0.5 & - & - \\
\hline 4 & - & 0.5 & 0.5 & 0.25 \\
\hline 5 & - & - & 0.75 & 0.5 \\
\hline 6 & - & - & 1.0 & 0.75 \\
\hline 7 & - & - & 0.5 & - \\
\hline 8 & - & 0.25 & 0.75 & - \\
\hline 9 & - & 0.5 & 1.0 & - \\
\hline 10 & - & 0.75 & 0.5 & - \\
\hline 11 & - & - & 0.75 & - \\
\hline 12 & - & - & 1.0 & \\
\hline 13 & - & - & & \\
\hline
\end{tabular}

\section{Statistical analysis}

Data collection was based on visual observation of single and multiple shoot induction, also on degree and morphology of callus. All data were analysed by calculating mean \pm standard error using analysis of variance by Generalized Linear Model of SAS 9.2 version. Means were separated using Duncan's multiple range tests at 0.05 probability level.

\section{Results}

\section{Surface sterilization for explants of P. erosus}

Stem and leaf explants sterilized with 5 and $10 \% \mathrm{v} / \mathrm{v} \mathrm{NaClO}$ at both 5 and 10 mins, were contaminated and $15 \% \mathrm{v} / \mathrm{v}$ surface sterilized explants at both durations were observed dead a week after inoculation in MS media (Figure 1).

Nodal explants sterilized with $10 \% \mathrm{v} / \mathrm{v} \mathrm{NaClO}$ solution at both $5 \mathrm{~min}(20 \%)$ and $10 \mathrm{~min}(30 \%)$ regenerated clean shoots two weeks after inoculation in MS media. While nodal explants sterilized with $5 \% \mathrm{v} / \mathrm{v}$ and $15 \% \mathrm{v} / \mathrm{v} \mathrm{NaClO}$ solutions were contaminated and dead respectively, with no shoot formation (Figure 1).

Root tuber explants sterilized with $15 \% \mathrm{v} / \mathrm{v} \mathrm{NaClO}$ solution for 10 min were observed clean (50\%) with callus formation. While the other treatments ( $5 \%$ and $10 \%)$ became contaminated without callus formed, one week after inoculation (Figure 1). 
P. erosus seeds sterilized with $5 \% \mathrm{v} / \mathrm{v} \mathrm{NaClO}$ for 5 and 10 min. germinated with $40 \%$ and $30 \%$ clean seedlings respectively after two weeks. Seeds sterilized with $10 \% \mathrm{v} / \mathrm{v} \mathrm{NaClO}$ solution for 5 min germinated with $40 \%$ of clean seedlings. Seeds sterilized with $10 \% \mathrm{v} / \mathrm{v} \mathrm{NaClO}$ solution for $10 \mathrm{~min}$ had the highest percentage of clean seedlings (90\%) (Figure 1).

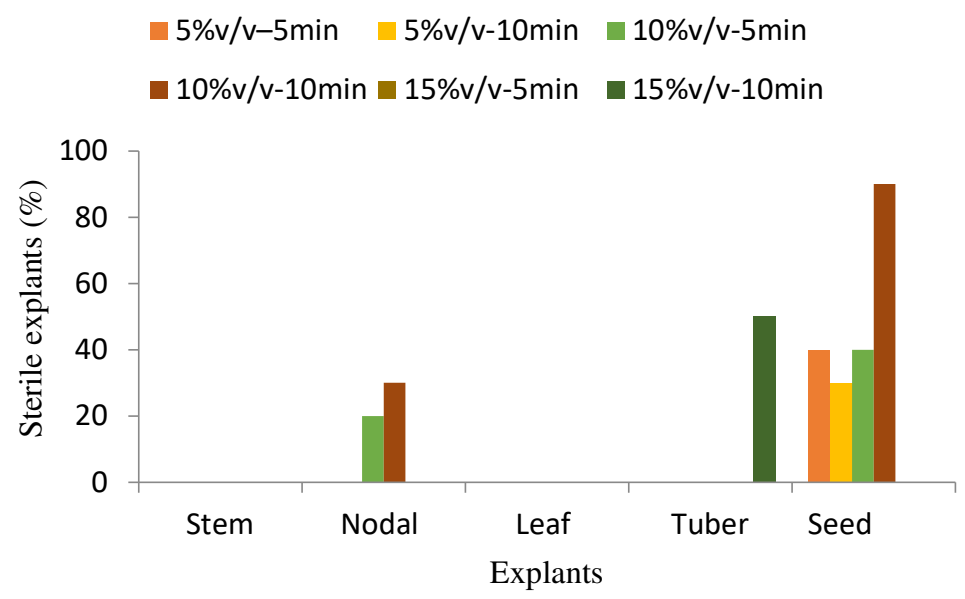

Figure 1. Effect of different concentrations of $\mathrm{NaClO}$ solution on surface sterilization of $P$. erosus explants $(n=10)$

\section{Direct regeneration and callus formation on nodal explants of $P$. erosus}

P. erosus nodal explant cultured in MS medium supplemented with $1.0 \mathrm{mg} / \mathrm{L}$ BA only and in MS medium supplemented with $1.0 \mathrm{mg} / \mathrm{L} \mathrm{BA}+0.5 \mathrm{mg} / \mathrm{L}$ NAA gave the significantly highest number of multiple shoots and also gave a significantly higher degree of friable callus compare to other treatments (Table 2 and Figure $2 \mathrm{~A} \& \mathrm{~B})$. The different concentrations of kinetin and 2, 4-D supplements in MS media also gave considerable number of multiple shoots, it produced moderate callus that are compact in nature or no callus production at all (Table 2 and Figure 2C).

Table 2. Effect of different concentrations of auxins (NAA and 2, 4-D) and cytokinins (BA and kinetins) on shoot induction and callus formation from nodal explants of in vitro germinated P. erosus

\begin{tabular}{|c|c|c|c|c|c|c|}
\hline $\begin{array}{l}\text { Treatment } \\
(\mathrm{mg} / \mathrm{L})\end{array}$ & $\begin{array}{c}\text { Quantity } \\
\text { of } \\
\text { shoot }\end{array}$ & $\begin{array}{c}\text { No. of shoot } \\
\text { induced per } \\
\text { explant }\end{array}$ & $\begin{array}{l}\text { Mean no. of } \\
\text { shoots } \pm S . E\end{array}$ & $\begin{array}{c}\text { Callus } \\
\text { formation } \\
(\text { Mean } \pm \text { S.E })\end{array}$ & $\begin{array}{l}\text { Degree } \\
\text { of callus }\end{array}$ & $\begin{array}{c}\text { Morphology } \\
\text { of callus } \\
\text { formation }\end{array}$ \\
\hline MS (Control) & $S$ & $1.33 \pm 0.33^{\mathrm{d}}$ & $0.40 \pm 0.02^{\text {cd }}$ & $0.00 \pm 0.00$ & - & - \\
\hline $\mathrm{MS}+1.0 \mathrm{BA}$ & M & $4.00 \pm 0.00^{\mathrm{a}}$ & $6.80 \pm 0.11^{\mathrm{a}}$ & $4.00 \pm 0.00^{\mathrm{a}}$ & ++ & Friable \\
\hline $\mathrm{MS}+1.0 \mathrm{BA}+0.5 \mathrm{NAA}$ & $\mathrm{M}$ & $3.00 \pm 0.00^{\mathrm{ab}}$ & $3.40 \pm 0.20^{\mathrm{b}}$ & $3.00 \pm 0.00^{\mathrm{ab}}$ & ++ & Friable \\
\hline $\mathrm{MS}+0.5 \mathrm{NAA}$ & $\mathrm{M}$ & $2.33 \pm 0.33^{\mathrm{bcd}}$ & $1.26 \pm 0.12^{\mathrm{bc}}$ & $0.00 \pm 0.00$ & - & - \\
\hline $\mathrm{MS}+0.5 \mathrm{Kin}+0.252,4-\mathrm{D}$ & $S$ & $2.33 \pm 0.33^{\mathrm{bcd}}$ & $1.20 \pm 0.14^{\mathrm{bc}}$ & $2.33 \pm 0.33^{\mathrm{bcd}}$ & ++ & Compact \\
\hline $\mathrm{MS}+0.75 \mathrm{Kin}+0.52,4-\mathrm{D}$ & $S$ & $1.67 \pm 0.33^{\mathrm{cd}}$ & $0.52 \pm 0.34^{\mathrm{c}}$ & $1.67 \pm 0.33^{\text {cd }}$ & ++ & Compact \\
\hline $\mathrm{MS}+1.0 \mathrm{Kin}+0.752,4-\mathrm{D}$ & - & $0.00 \pm 0.00$ & $0.00 \pm 0.00$ & $2.67 \pm 0.33^{\mathrm{bc}}$ & ++ & Compact \\
\hline $\mathrm{MS}+0.25 \mathrm{NAA}+0.5 \mathrm{Kin}$ & - & $0.00 \pm 0.00$ & $0.00 \pm 0.00$ & $2.00 \pm 0.57^{\mathrm{bcd}}$ & ++ & Compact \\
\hline $\mathrm{MS}+0.5 \mathrm{NAA}+0.75 \mathrm{Kin}$ & - & $0.00 \pm 0.00$ & $0.00 \pm 0.00$ & $1.67 \pm 0.33^{\mathrm{cd}}$ & ++ & Compact \\
\hline $\mathrm{MS}+0.75 \mathrm{NAA}+1.0 \mathrm{Kin}$ & $S$ & $2.67 \pm 0.33^{\mathrm{bc}}$ & $1.00 \pm 0.10^{c}$ & $1.67 \pm 0.33^{\text {cd }}$ & ++ & Compact \\
\hline $\mathrm{MS}+0.5 \mathrm{Kin}$ & $S$ & $1.33 \pm 0.33^{\mathrm{d}}$ & $0.60 \pm 0.42^{c}$ & $1.33 \pm 0.33^{\mathrm{d}}$ & ++ & Compact \\
\hline $\mathrm{MS}+0.75 \mathrm{Kin}$ & M & $2.67 \pm 0.33^{b c}$ & $2.40 \pm 0.31^{\mathrm{b}}$ & $0.00 \pm 0.00$ & - & - \\
\hline $\mathrm{MS}+1.0 \mathrm{Kin}$ & $\mathrm{M}$ & $2.81 \pm 0.33^{b c}$ & $2.80 \pm 0.42^{b}$ & $1.68 \pm 0.57^{\mathrm{bcd}}$ & ++ & Compact \\
\hline
\end{tabular}


Values with the same superscript in a column are not significantly different from each other at $\mathrm{P} \leq 0.05 .(\mathrm{n}=10)$. $S$ (Single Shoot), M (Multiple Shoots). (+ Scanty callus), (++ Moderate callus), (+++ Massive callus)

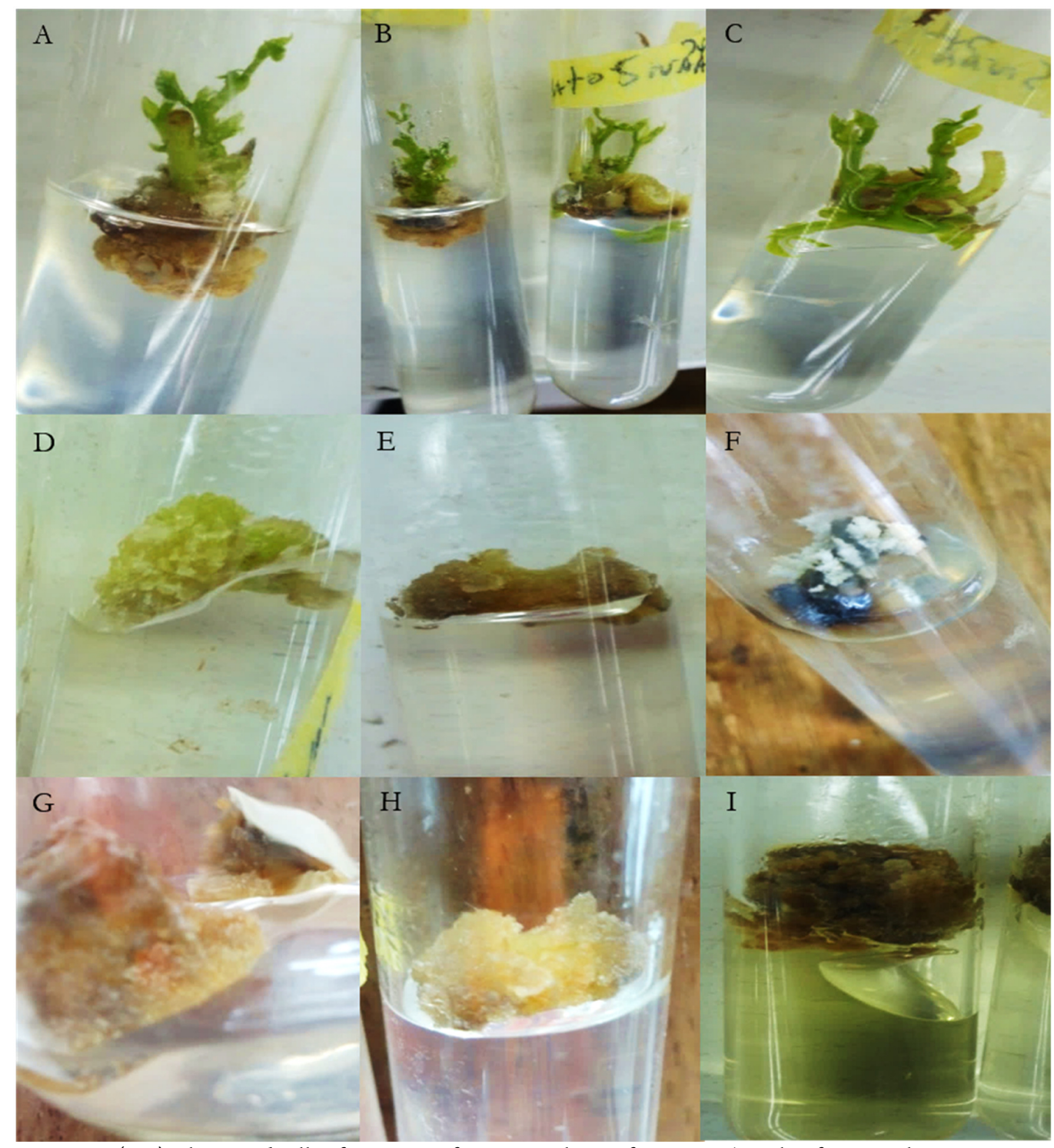

Figure 2(A-I). Shoot and callus formation of in vivo explants of P. erosus 4 weeks after inoculation on MS media + PGR

(A) Nodal explants with multiple shoots and basal callus on MS media + 1.0 BA mg/L (B) Nodal explants with multiple shoots and basal callus on MS media $+1.0 \mathrm{mg} / \mathrm{L} \mathrm{BA}+0.5 \mathrm{mg} / \mathrm{L}$ NAA (C) Nodal explants with multiple shoots on MS media $+0.5 \mathrm{mg} / \mathrm{L}$ NAA. (D) Stem explants forming friable callus on MS media $+1.0 \mathrm{mg} / \mathrm{L} \mathrm{BA}+0.5$ $\mathrm{mg} / \mathrm{L}$ NAA. (E) Stem explants forming friable callus on MS media $+0.5 \mathrm{mg} / \mathrm{L}$ NAA (F) Stem explants with compact callus on MS media $+0.75 \mathrm{mg} / \mathrm{L} \mathrm{NAA}+1.0 \mathrm{mg} / \mathrm{L} \mathrm{Kin.} \mathrm{(G)} \mathrm{Tuber} \mathrm{explants} \mathrm{with} \mathrm{friable} \mathrm{callus} \mathrm{on} \mathrm{MS} \mathrm{media}+1.0$ $\mathrm{mg} / \mathrm{L} \mathrm{BA}+0.5 \mathrm{mg} / \mathrm{L}$ NAA. (H) Tuber explants with friable callus on MS media $+1.0 \mathrm{mg} / \mathrm{L} \mathrm{BA}$ only (I) Tuber explants with compact callus and phenolic exudates on MS media $+1.0 \mathrm{mg} / \mathrm{L} \mathrm{Kin}$

\section{Direct regeneration and callus formation on stem explant of $P$. erosus}

Stem explants from In vitro germinated P. erosus cultured in MS media supplemented with different concentrations of auxins and cytokinins did not produce any shoot, but callus was formed. Stem explants cultured in MS medium supplemented with $1.0 \mathrm{mg} / \mathrm{L} \mathrm{BA}+0.5 \mathrm{mg} / \mathrm{L}$ NAA and in MS media supplemented 
in $0.5 \mathrm{mg} / \mathrm{L}$ NAA only, gave the significantly highest friable callus production $(\mathrm{P}<0.05)$ (Table 3 and Figure $2 \mathrm{D}, \mathrm{E}$ and $\mathrm{F})$.

Table 3. Effect of different concentrations of auxins (NAA and 2, 4-D) and cytokinins (BA and kinetins) on callus formation from stem explants of in vitro germinated $P$. erosus

\begin{tabular}{|c|c|c|c|}
\hline $\begin{array}{c}\text { Treatment } \\
(\mathrm{mg} / \mathrm{L})\end{array}$ & $\begin{array}{l}\text { Callus formation } \\
(\text { Mean } \pm \text { S.E })\end{array}$ & $\begin{array}{l}\text { Degree of } \\
\text { callus }\end{array}$ & $\begin{array}{c}\text { Morphology } \\
\text { of callus }\end{array}$ \\
\hline MS (Control) & $0.00 \pm 0.00^{\mathrm{d}}$ & - & - \\
\hline $\mathrm{MS}+1.0 \mathrm{BA}$ & $2.67 \pm 0.67^{\mathrm{bc}}$ & ++ & Friable \\
\hline $\mathrm{MS}+1.0 \mathrm{BA}+0.5 \mathrm{NAA}$ & $4.33 \pm 0.33^{\mathrm{a}}$ & ++ & Friable \\
\hline $\mathrm{MS}+0.5 \mathrm{NAA}$ & $3.67 \pm 0.67^{\mathrm{ab}}$ & ++ & Friable \\
\hline $\mathrm{MS}+0.5 \mathrm{Kin}+0.252,4-\mathrm{D}$ & $1.33 \pm 0.33^{\text {cd }}$ & ++ & Friable \\
\hline $\mathrm{MS}+0.75 \mathrm{Kin}+0.52,4-\mathrm{D}$ & $1.67 \pm 0.33^{c}$ & + & Friable \\
\hline $\mathrm{MS}+1.0 \mathrm{Kin}+0.752,4-\mathrm{D}$ & $1.00 \pm 0.00^{\text {cd }}$ & ++ & Friable \\
\hline $\mathrm{MS}+0.25 \mathrm{NAA}+0.5 \mathrm{Kin}$. & $2.33 \pm 0.33^{\mathrm{bc}}$ & ++ & Compact \\
\hline $\mathrm{MS}+0.5 \mathrm{NAA}+0.75 \mathrm{Kin}$ & $2.33 \pm 0.44^{\mathrm{bc}}$ & ++ & Compact \\
\hline $\mathrm{MS}+0.75 \mathrm{NAA}+1.0 \mathrm{Kin}$ & $3.33 \pm 0.33^{\mathrm{ab}}$ & +++ & Compact \\
\hline $\mathrm{MS}+0.5 \mathrm{Kin}$ & $2.33 \pm 0.67^{\mathrm{bc}}$ & +++ & Compact \\
\hline $\mathrm{MS}+0.75 \mathrm{Kin}$ & $2.33 \pm 0.88^{b c}$ & ++ & Compact \\
\hline $\mathrm{MS}+1.0 \mathrm{Kin}$ & $2.67 \pm 0.67^{\mathrm{bc}}$ & + & Compact \\
\hline
\end{tabular}

Values with the same superscript in column are not significantly different from each other at $\mathrm{P} \leq 0.05 .(\mathrm{n}=10)$. (+

Scanty callus), (++ Moderate callus), (+++ Massive callus)

\section{Direct regeneration and callus formation on tuber explant of $P$. erosus}

Friable callus was observed on tuber explant cultured on MS media supplemented with $1.0 \mathrm{mg} / \mathrm{L} \mathrm{BA}+$ $0.5 \mathrm{mg} / \mathrm{L}$ NAA, $1.0 \mathrm{mg} / \mathrm{L} \mathrm{BA}$ alone and $0.5 \mathrm{mg} / \mathrm{L} \mathrm{NAA}$ alone. Compact callus with brownish exudates were observed on tuber explants cultured on MS media supplemented with $1.0 \mathrm{mg} / \mathrm{L}$ Kin alone, $0.75 \mathrm{mg} / \mathrm{L} \mathrm{Kin}$ alone, $0.25 \mathrm{mg} / \mathrm{L} \mathrm{NAA}+0.5 \mathrm{mg} / \mathrm{L} \mathrm{Kin}$ and $0.75 \mathrm{mg} / \mathrm{L} \mathrm{NAA}+1.0 \mathrm{mg} / \mathrm{L}$ Kin (Table 4).

Callus formation was significantly highest in tuber explants cultured on MS medium supplemented with $1.0 \mathrm{mg} / \mathrm{L} \mathrm{BA}+0.5 \mathrm{mg} / \mathrm{L} \mathrm{NAA}$ (Figure $2 \mathrm{G}$ ), but not significantly higher than callus produced on tuber explants cultured on media supplemented with $1.0 \mathrm{mg} / \mathrm{L}$ Kin alone (Figure $2 \mathrm{I}$ ) and $1.0 \mathrm{mg} / \mathrm{L}$ BA alone (Figure $2 \mathrm{H}$ ) $(\mathrm{P}<0.05)($ Table 4$)$.

Table 4. Effect of different concentrations of auxins (NAA and 2, 4-D) and cytokinins (BA and kinetins) on callus formation from tuber explants of $P$. erosus

\begin{tabular}{|c|c|c|c|}
\hline $\begin{array}{l}\text { Treatment } \\
(\mathrm{mg} / \mathrm{L})\end{array}$ & $\begin{array}{l}\text { Callus formation } \\
\text { (Mean } \pm \text { S.E })\end{array}$ & Degree of callus & $\begin{array}{c}\text { Morphology of } \\
\text { callus }\end{array}$ \\
\hline MS (Control) & $0.00 \pm 0.00$ & - & - \\
\hline $\mathrm{MS}+1.0 \mathrm{BA}$ & $3.00 \pm 0.00^{\mathrm{abc}}$ & +++ & Friable \\
\hline $\mathrm{MS}+1.0 \mathrm{BA}+0.5 \mathrm{NAA}$ & $4.00 \pm 0.57^{\mathrm{a}}$ & +++ & Friable \\
\hline $\mathrm{MS}+0.5 \mathrm{NAA}$ & $2.00 \pm 1.00^{\mathrm{bcd}}$ & ++ & Friable \\
\hline $\mathrm{MS}+0.5 \mathrm{Kin}+0.252,4-\mathrm{D}$ & $1.33 \pm 0.33^{\mathrm{def}}$ & ++ & Compact \\
\hline $\mathrm{MS}+0.75 \mathrm{Kin}+0.52,4-\mathrm{D}$ & $1.33 \pm 0.33^{\mathrm{def}}$ & ++ & Compact \\
\hline $\mathrm{MS}+1.0 \mathrm{Kin}+0.75$ 2,4-D & $0.33 \pm 0.33^{\mathrm{ef}}$ & ++ & Compact \\
\hline MS+0.25 NAA+0.5Kin. & $1.67 \pm 0.33^{\text {cde }}$ & ++ & Compact \\
\hline $\mathrm{MS}+0.5 \mathrm{NAA}+0.75 \mathrm{Kin}$ & $2.33 \pm 0.33^{\mathrm{bcd}}$ & ++ & Compact \\
\hline $\mathrm{MS}+0.75 \mathrm{NAA}+1.0 \mathrm{Kin}$ & $1.33 \pm 0.33^{\mathrm{def}}$ & + & Compact \\
\hline $\mathrm{MS}+0.5 \mathrm{Kin}$ & $1.00 \pm 0.57^{\text {def }}$ & ++ & Compact \\
\hline $\mathrm{MS}+0.75 \mathrm{Kin}$ & $2.33 \pm 0.33^{\text {bcd }}$ & ++ & Compact \\
\hline
\end{tabular}




\begin{tabular}{|c|c|c|c|}
\hline MS+1.0Kin & $3.33 \pm 0.33^{\mathrm{ab}}$ & ++ & Compact \\
\hline
\end{tabular}

Values with the same superscript in column are not significantly different from each other at $P \leq 0.05$. ( $n=10)$ ( + Scanty

callus), (++ Moderate callus), (+++ Massive callus)

Direct regeneration and callus formation on leaf explant of $P$. erosus

There were no shoot or callus formation on leaf explants of $P$. erosus inoculated on MS basal medium and on MS media supplemented with various concentrations of BA or Kinetin alone or in combinations with 2, 4-D and NAA four weeks after inoculation.

Effect of different concentrations of hormones on shoot formation in different explants of P. erosus

Multiple and single shoots were formed from nodal explants of $P$. erosus for the various concentrations of BA or Kinetin alone or in combinations with 2, 4-D and NAA four weeks after inoculation. Shoot formation was suppressed on nodal explants inoculated on MS media supplemented with higher concentrations of Kinetin in combination with NAA or 2,4-D. There was no shoot formed on stem, tuber and leaf explants for the various concentrations of BA or Kinetin alone or in combinations with 2, 4-D and NAA four weeks after inoculation (Figure 3).

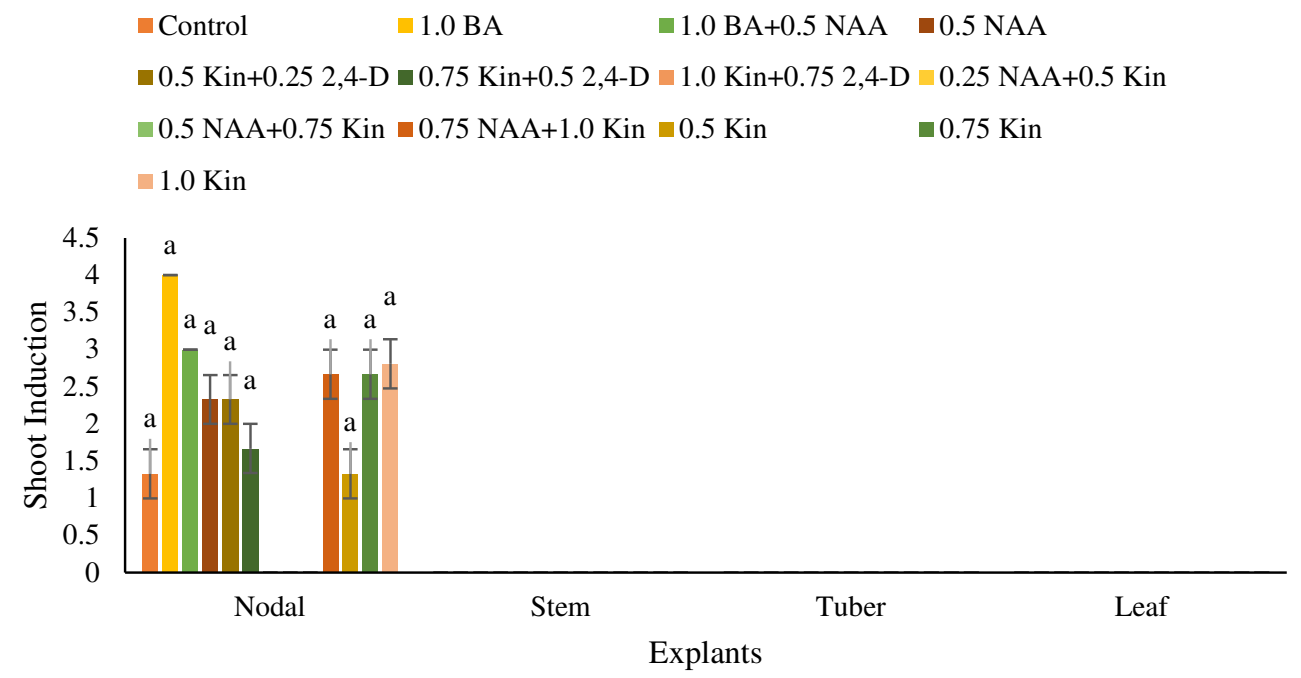

Figure 3. Effect of different concentrations of auxins (NAA and 2, 4-D) and cytokinins (BA and kinetins) on shoot formation in different explants of P. erosus

Values with the same label across different plant organs (explants) are not significantly different from each other at $\mathrm{P} \leq$ 0.05. $(\mathrm{n}=10)$

Effect of different concentrations of hormones on callus formation in different explants of P. erosus

Callus formation was significantly higher in nodal explants inoculated on MS medium supplemented with $1.0 \mathrm{mg} / \mathrm{L} \mathrm{BA}$ than in other explants, except for tuber explant in which there was no significant difference $(\mathrm{P} \leq 0.05)$. Stem and tuber explants inoculated on media supplemented with $1.0 \mathrm{mg} / \mathrm{L} \mathrm{BA}+0.5 \mathrm{mg} / \mathrm{L} \mathrm{NAA}$ gave a high quantity of callus but not significantly higher $(\mathrm{P} \leq 0.05)$ than that of nodal explants. Callus formation was significantly higher $(\mathrm{P} \leq 0.05)$ in stem explant inoculated on media supplemented with $0.5 \mathrm{mg} / \mathrm{L}$ NAA than in tuber, while there was no callus initiation on nodal and leaf explant. Callus initiated on nodal, stem and tuber explants inoculated on MS media supplemented with $0.5 \mathrm{mg} / \mathrm{L} \mathrm{Kin.} \mathrm{+} \mathrm{0.24} \mathrm{mg/L} \mathrm{2,4-D,} \mathrm{0.75}$ $\mathrm{mg} / \mathrm{L} \mathrm{Kin}+0.5 \mathrm{mg} / \mathrm{L} 2,4-\mathrm{D}$ and $1.0 \mathrm{Kin}+0.75$ 2,4-D Kin were not significantly different from one another $(\mathrm{P} \leq 0.05)$. Callus formation on nodal, stem and tuber explants inoculated on MS media supplemented with $0.25 \mathrm{mg} / \mathrm{L} \mathrm{NAA}+0.5 \mathrm{mg} / \mathrm{L} \mathrm{Kin}, 0.5 \mathrm{mg} / \mathrm{L} \mathrm{NAA}+0.75 \mathrm{mg} / \mathrm{L} \mathrm{Kin}$ and $0.75 \mathrm{mg} / \mathrm{L} \mathrm{NAA}+1.0 \mathrm{mg} / \mathrm{L} \mathrm{Kin} \mathrm{were}$ not significantly different from one another $(\mathrm{P} \leq 0.05)$. Callus formation was more on stem explants than in 
tuber explants inoculated on MS media supplemented with $0.5 \mathrm{mg} / \mathrm{L} \mathrm{Kin}$, but was not significantly different $(\mathrm{P} \leq 0.05)$ from callus formed on the nodal explants. Callus formation was more on tuber explants than on nodal explants inoculated on MS media supplemented with $1.0 \mathrm{mg} / \mathrm{L}$ Kin, but was not significantly different from callus formed on the stem explants $(\mathrm{P} \leq 0.05)$ (Figure 4).

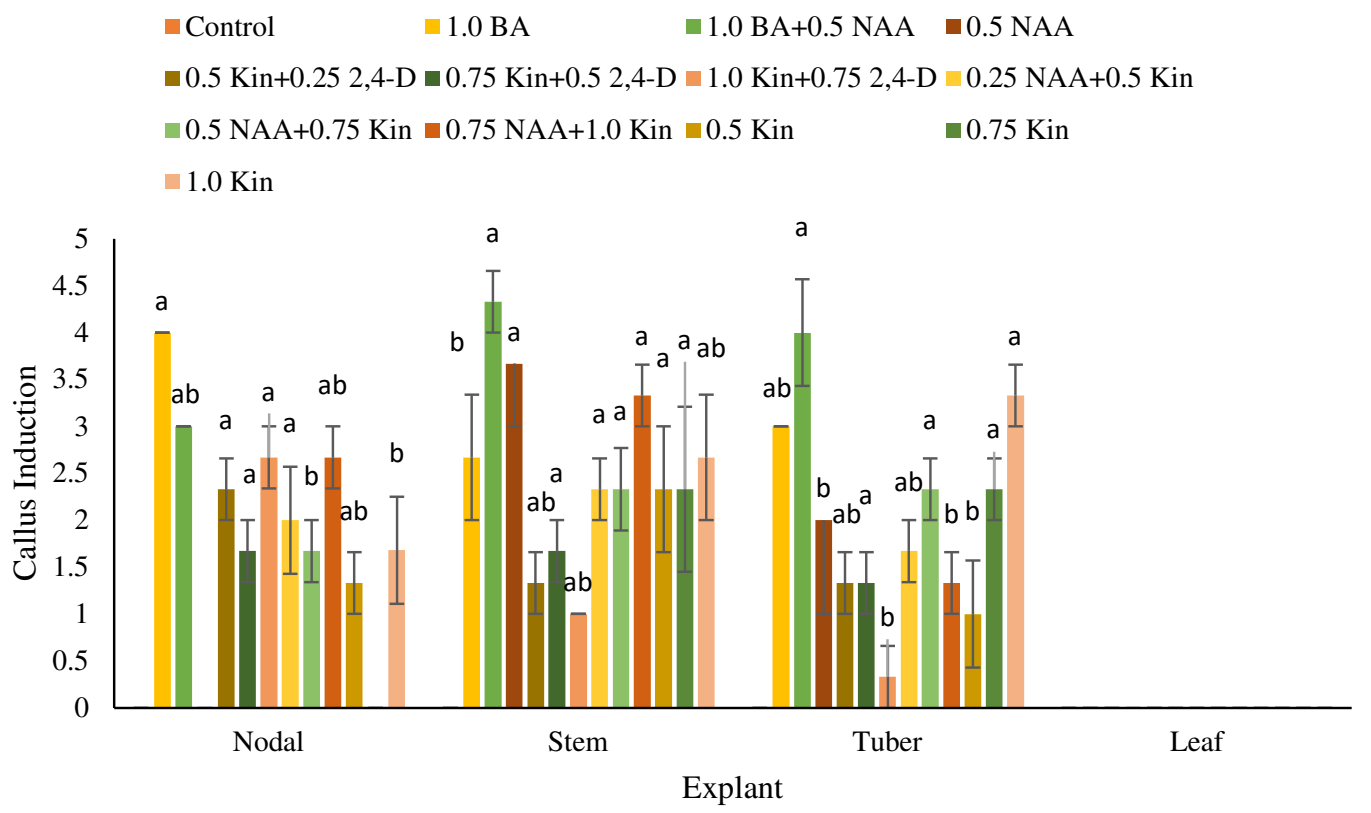

Figure 4. Effect of different concentrations of auxins (NAA and 2, 4-D) and cytokinins (BA and kinetins) on callus formation in different explants of $P$. erosus

Values with the same label across different plant organs (explants) are not significantly different from each other at $\mathrm{P} \leq$ 0.05. $(\mathrm{n}=10)$

\section{Discussion}

\section{Surface sterilization of P. erosus explants}

Contaminations in culture media could be introduced from many sources such as pathogen or microbial infections on plant materials collected from the field, contaminations from reagents, unsterilized laboratory equipment, improper handling of culture media etc. These could promote growth of microorganisms on cultured media. Surface sterilization of explants from field grown plants intended for in vitro culture is therefore of utmost importance. The percentage contamination of $P$. erosus explants (nodal, leaf and stem) obtained from the plants grown in the field in this study was very high, for the different concentrations of $\mathrm{NaClO}$ solutions used in surface sterilization at different durations. This could be as a result of plant pathogens present in the environment where the plants were cultivated. Some of which can be insect infestations which bring in fungal and bacterial contamination (Smith, 2008). Stems and leaves of $P$. erosus cultivated in the field were observed to have epidermal hairs (i.e. pubescent), which will be a good anchorage for microorganisms causing contaminations (Marvasi et al., 2012). Surfaces covered with thick wax such as the succulents and epidermal hairs can also trap microorganisms. Additionally, many plants have microbial contamination within the vascular system, and intercellular spaces in leaf mesophyll (Miyazaki et al., 2013). Legumes particularly have been reported to be highly susceptible to insect pests and diseases which causes significant damage to the plant in the field (Srinivasan and Yule, 2014), of which, P. erosus, might not be an exception. A higher concentration 
of $\mathrm{NaClO}$ solutions (15\%) was noted to be too strong on the tissues of the nodal, stem and leaf explants, resulting in death of the explants. This shows that higher concentration of the sterilant is toxic to the explants. On the other hand, lower concentration of $\mathrm{NaClO}$ were found to be ineffective in sterilization of tuber explants, while a higher concentration gave an average response. This is because maintaining an aseptic condition for plant organs that have been in contact with the soil particles which usually contains microorganisms is highly tasking. This observation is supported by the report of Bunn and Tan (2002), which stated that plant material growing in the soil (roots, tubers, bulbs) or near the soil surface (stolons, rhizomes, shoots from rosettes) is usually more difficult to clean than aerial plant part. Tuber explants, therefore, require extra care, like peeling the skin off the edible tuber to remove the part of the explant that has been in direct contact with the soil and microorganisms in the soil, before surface sterilization. The tuber explants were able to survive the higher concentration $(15 \% \mathrm{NaClO})$ of the sterilant being hardier unlike the nodal, stem and particularly the leaf explants, which could not survive the higher concentration of $\mathrm{NaClO}$ solution.

An alternative way of getting explants for in vitro culture is through in vitro germination of seeds. Miransari and Smith (2014) suggested that seeds can be aseptically germinated to provide clean explants from the root, hypocotyl, cotyledon, and shoot. P. erosus aseptically germinated in vitro were observed to develop stems, leaves and nodes that are without epidermal hairs (i.e. glabrous). This eliminated the possibility of microbial infections caused by pathogens carried by trichomes on the field grown plant organs. This observation is supported by the research of Lochlainn (2011) in which P. erosus seeds were germinated in vitro for the purpose of micro propagation. Kumar and Chandra (2009) also reported that in vitro grown seedlings can be used as the starting plant material for tissue culture because they can be quickly raised and chances of bacterial and fungal contaminations in the tissue cultures can be minimized. In this study, seeds sterilized with $10 \% \mathrm{NaClO}$ solution for 10 minutes and germinated in vitro were discovered to be the best way of getting sterile nodal, stem and leaf explants for the in vitro propagation of $P$. erosus. While tuber explants sterilized with $15 \% \mathrm{NaClO}$ for 10 minutes also gave an average response.

\section{Effect of different hormones on direct regeneration and callus formation in P. erosus}

Nodal explants inoculated on MS basal media only had single shoot inductions. This was because nodal explants have been reported to have a great organogenic potential for direct shoot regeneration (Neves et al., 2001; Shaiket al., 2010; Ayisire et al., 2012). Although, nodal explants on media supplemented with $1.0 \mathrm{mg} / \mathrm{L}$ $\mathrm{BA}$ alone and $1.0 \mathrm{BA}$ and $0.5 \mathrm{mg} / \mathrm{L}$ NAA produced multiple shoots with friable callus, those on media supplemented with $1.0 \mathrm{mg} / \mathrm{L}$ Kin alone and $0.75 \mathrm{Kin}$ alone produced multiple shoots with compact callus. This is supported by Shagufta et al. (2007) in which BA was reported to be an ideal hormone for shoot multiplication in grain legumes. Shaiket al. (2010) also reported that the most effective cytokinin for shoot multiplication of Lessertia frutescens (a member of the family Fabaceae) using nodal explants was BA. Kumar and Chandra (2009) observed a considerable increase in the size of explant followed by multiple shoot induction within 4-6 weeks of incubation of Stylosanthes seabrana. The addition of BA alone and Kinetin alone in the medium resulted in the induction of multiple shoots. Neves et al. (2001) also used cytokinin for multiple shoot induction in Medicago truncatula and reported BA to be the best for inducing maximum number of shoots. The two cytokinins used in this study, BA and Kinetin gave multiple shoot induction, even though the amount of multiple shoots induced was significantly lower in Kinetin compared to BA. In this study, the combination of $1.0 \mathrm{mg} / \mathrm{L} \mathrm{BA}$ and $0.5 \mathrm{mg} / \mathrm{L}$ NAA supplemented in MS medium produced multiple shoots from nodal explants. However, addition of NAA in the medium reduced the regeneration efficiency of the nodal explants. This is contrary to the study reported by Rout (2005) that in vitro shoot multiplication from nodal explants of Clitoria ternatea on MS basal medium supplemented with BA with inclusion of NAA promoted higher rates of shoot multiplication than BA alone. Lochlainn (2011) observed a contrary report of nodal explants inoculated on MS media supplemented with NAA and BA producing only callus.

Stem, leaf and tuber explants of $P$. erosus in this study did not produce shoots in the MS media supplemented with different concentrations of auxins and cytokinin. The inability of these explants to produce 
shoot might be because of their morphology, developmental stage and/or choice and concentration of hormones used. It could also be because different explants and even species respond differently to the same treatment (Sakpere et al., 2011).

Production of callus from fragments of stems, leaves and roots are mainly carried out to determine the culture conditions required by the explants to survive and grow, study cell development, exploit products coming from primary and secondary metabolism and obtain cell suspension in propagation. It can also pave the way for isolating economically valuable phytochemicals, which can provide an alternative way of collecting plant materials from natural sources (Berkov et al., 2009; Ogita et al., 2009). In the areas of plant biotechnology, callus and cell culture carries a special role for producing medicinal and bioactive compounds in large-scale from plants (Monokesh, 2014). Phytochemicals are serving as a major source of pharmaceuticals, flavors, agrochemicals, colors, bio-pesticides and food additives. Cytokinins have been reported to play an important role in callogenesis (He et al., 2002) while auxin affects the quality of callus formation (Chen et al., 2002). In this study, high response of friable callus which could be further used for suspension culture for the purpose of embryogenesis, were produced from nodal, stem and tuber explants inoculated in MS medium supplemented with $1.0 \mathrm{mg} / \mathrm{L} \mathrm{BA}$ alone and in MS medium supplemented with $1.0 \mathrm{mg} / \mathrm{L} \mathrm{BA}$ plus $0.5 \mathrm{mg} / \mathrm{L}$ NAA. While nodal, stem and tuber explants inoculated on MS medium supplemented with Kin alone, combination of Kin with 2, 4-D and combination of NAA with Kin produced compact callus which could not be used for suspension culture. However, for stem explants addition of 2, 4-D to Kin. induced friable callus formation. Gupta et al. (2005) also obtained callus from stem and root segments of Boerhaavia diffusa plantlets produced in vitro on MS medium supplemented with $0.5 \mathrm{mg} / \mathrm{L} \mathrm{BA}$ and $1.0 \mathrm{mg} / \mathrm{L}$ NAA. Although, in this research, stem explants gave a relatively higher response of friable callus compared to nodal and tuber explants. However, leaf explants inoculated in MS medium alone and in MS medium supplemented with different concentrations and combinations of BA, NAA, Kin and 2,4-D, where unable to produce callus.

\section{Conclusions}

In determining the best explants for in vitro propagation of $P$. erosus, nodal explants were discovered to be the best for shoot regeneration. Stem, tuber and nodal explants are callogenic and are good sources of callus that could be used for production of secondary metabolites and genetic transformation studies, with stem explants having higher callus induction capacity.

\section{Authors' Contributions}

OIA, SAMA and ABJ conceived the study design. OIA and AMS carried out all experiments. OIA drafted the first manuscript. OIA and SAMA improved the manuscripts. All authors read and approved the final manuscript.

\section{Acknowledgements}

This research received no specific grant from any funding agency in the public, commercial, or not-forprofit sectors. 
Obisesan IA et al. (2021). Not Sci Biol 13(1):10844

\section{Conflict of Interests}

The authors declare that there are no conflicts of interest related to this article.

\section{References}

Ayisire BE, Ayisire ER, Akinbola PO (2012). Studies on Hollarrhena floribunda (G. Don) Durand and Schinz: Germination and seedling growth, and preliminary investigations on callus induction and plant regeneration. African Journal of Agricultural Research 7(47):6297-6304. https://doi.org/10.5897/AJAR12.1626

Bergthaller W, Dijkink BH, Langelaan HC, Vereijken JM (2001). Legume protein preparation and functional properties. Food 45(1):396-398. https://doi.org/10.1002/1521-3803

Berkov S, Pavlov A, Georgiev V, Bastida J, Burrus M, Ilieva M, Codina C (2009). Alkaloid synthesis and accumulation in Leucojum aestivum in vitro cultures. Natural Product Communications 4(3):359-64. https://doi.org/10.1177/1934578X0900400328

Bunn E, Tan BH (2002). Microbial contaminants in plant tissue culture propagating. In: Sivasithamparam K, Dixon KW (Eds). Microorganisms in plant conservation and biodiversity. The Netherlands: Kluwer Academic Publishers, Dordrecht pp 307-335. https://link.springer.com/chapter/10.1007/0-306-48099-9_1

Cassells AC (1991). Problems in tissue culture: culture contamination. In: Debergh PC, Zimmerman RH (Eds). Micropropagation. Springer, Dordrecht https://doi.org/10.1007/978-94-009-2075-0_3

Chen ZL, Yan ZL, Xue H, Feng XD, Cao JY (2002). In vitro culture leaves and plantlet regeneration of Ziziphus jujube 'Zhanhual Dongzao'. Plant Physiology Communique 38(6):584. http://en.cnki.com.cn/Article_en/CJFDTotalZWSL200206019.htm

Gupta RK, Tandon VR (2005). An experimental evaluation of anticonvulsant activity of Vitex negundo. Indian Journal of Physiology and Pharmacology 49:163-172. https://www.ijpp.com/IJPP\%20archives/2005_49_2/199-205.pdf

He ZY, Wang YG, Shi WL, Yin MQ (2002). Tissue culture and plantlet regeneration of leaf of Ziziphus jujuba. Plant Physiology Communiques 38(5):457. https://link.springer.com/article/10.1007/s11240-017-1274-8

Kumar S, Chandra A (2009). Direct plant regeneration via multiple shoot induction in Stylosanthes seabrana. Cytologia 74(4):391-399. https://doi.org/10.1508/cytologia.74.391

Lochlainn NGK (2011). Genetic improvement of under utilized legumes. Ph.D. Thesis, University of Nottingham, Germany.

Mahna N, Vahed SZ, Khani S (2013) Plant in vitro culture goes nano: nanosilver-mediated decontamination of ex vitro explants. Journal of Nanomedical and Nanotechology 4:161. https://doi:10.4172/2157-7439.1000161

Marvasi M, Donnarumma F, Frandi A, Mastromei G, Sterflinger K, Tiano P, Perito B (2012). Black microcolonial fungi as deteriogens of two famous marble statues in Florence, Italy. International Biodeterioration \& Biodegradation 68:36-44. https://doi.org/10.1016/j.ibiod.2011.10.011

Masood SB, Rizwana B (2010). Nutritional and functional properties of some promising legumes protein isolated. Pakistan Journal of Nutrition 9(4):373-379. http://pjbs.org/pjnonline/fin 1693.pdf

Miransari M, Smith DL (2014). Plant hormones and seed germination. Environmental and Experimental Botany 99:110121. https://doi.org/10.1016/j.envexpbot.2013.11.005

Miyazaki N, Nakagawa A, Iwasaki K (2013). Life cycle of phytoreoviruses visualized by electron microscopy and tomography. Frontier in Microbiology 4:306. https://doi.org/10.3389/fmicb.2013.00306

Monokesh KS, Shamima N, Shahedur R, Abu HMJ (2014). In vitro callus induction and plantlet regeneration of Achyranthes aspera L., a high value medicinal plant. Asian Pacific Journal of Tropical Biomedicine 4(1):40-46. https://doi.org/10.1016/S2221-1691(14)60206-9

Murashige T, Skoog F (1962). A revised medium from rapid growth and bioassays with tobacco tissue cultures. Physiologia Plantarum 15:473-497. https://doi.org/10.1111/j.1399-3054.1962.tb08052.x

Naval MM, Llacer G, Badenes ML, Giordani E (2009). Adventitious shoot regeneration from leaf explants of the Persimmon (Diospyros kaki Thunb.) cv. 'Rojo Brillante'. Acta Horticulturae 833:183-186. https://doi.org/10.17660/ActaHortic.2009.833.29 
Neves LO, Tomaz L, Fevereiro MPS (2001). Micropropagation of Medicago truncatula Gaertn. cv. Jemalong and Medicago truncatula ssp. Narbonensis. Plant Cell, Tissue and Organ Culture 67:81-84. https://doi.org/10.1023/A:1011699608494

Niedz RP, Bausher MG (2002). Control of in vitro contamination of explants from greenhouse- and field-grown trees. In Vitro Cell Developmental Biology-Plant 38:468-471. https://doi.org/10.1079/IVP2002316

Nikam TD, Savanth RS, Parage RS (2008). Micropropagation of Ceropegia hirsute Wt. and Arn. A starchy tuberous asclepiad. Indian Journal of Biotechnology 7:129-132.http://nopr.niscair.res.in/handle/123456789/7331

Ogita S, Miyazaki J, Godo T, Kato Y (2009). Possibility for selective accumulation of polyphenolics in tissue cultures of Senno (Lychnis senno Sieboldet Zucc.). Natural Product Communications 4(3):377-380. https://doi.org/10.1177/1934578X0900400312

Ojiewo C, Keatinge DJ, Hughes J, Tenkouano A, Nair R, Varshney RM, ... Silim S (2015). The role of vegetables and legumes in assuring food, nutrition and income security for vulnerable groups in Sub-Saharan Africa. World Medical and Health Policy 7(3):187-210. https://doi.org/10.1002/wmh3.148

Omamor IB, Asemota AO, Eke CR, Ezia EI (2007) Fungal contaminants of the oil palm tissue culture in Nigerian Institute for Oil Palm Research (NIFOR). African Journal of Agricultural Research 2(10):534-537. https://doi.org/10.5897/AJAR.9000361

Padonou SW, Hounyevou AK, Ahounou J, Houssou AJ, Fandohan P, ... Koudande DO (2013) Yam bean (Pachyrhizus erosus) tuber processing in Benin: production and evaluation of the quality of yam bean-gari and yam beanfortified gari. International Journal of Biological and Chemical Sciences 7(1):247-259. http://dx.doi.org/10.4314/ijbcs.v7ili.21

Rout GR (2005). Micropropagation of Clitoria ternatea Linn. (Fabaceae): an important medicinal plant. In Vitro Cellular \& Developmental Biology. Plant 41(4):516-519. https://doi.org/10.1079/IVP2005675

Sakpere AM, Ayisire ER, Abioye OI (2011) Potential of Launea taraxacifolia (Willd) Ex. C. Jeffrey for in vitro Regeneration. Notulae Scientia Biologicae 3(3):93-96.

Santos ACO, Cavalcanti MSM, Coelho LCBB (1996). Chemical composition and nutritional potential of yam bean seeds (Pachyrizus erosus L. Urban). Plant Foods for Human Nutrition 49:35-41. https://doi.org/10.1007/BF01092520

SAS Institute Inc. SAS 9.1.2 (2004). Qualification Tools User’s Guide. SAS Institute Inc., Cary, NC USA.

Sathyanaraya BN, Verghese DB (2007) Plant tissue culture: practices and new experimental protocols. IK International Pvt Ltd.

Shagufta N, Ali A, Siddique FA, Iqbal J (2007). Multiple shoot formation from different explants of chick pea (Cicerarietinum L.). Pakistan Journal of Botany 39(6):2067-2073. https://216321532/links/0912f50a52ee2ce256000000.pdf

Shahinozzaman M, Azad MAK, Amin MN (2012). In vitro clonal propagation of a fast-growing legume tree-Acacia angium Willd. employing cotyledonary node explants. Notulae Scientia Biologicae 4(2):79-85. https://doi.org/10.15835/nsb427553

Shaik S, Dewir YH, Singh N, Nicholas A (2010). Micropropagation and bioreactor studies of the medicinally important plant Lessertia (Sutherlandia) frutescens L. South African Journal of Botany 76(2):180-186. https://doi.org/10.1016/j.sajb.2009.10.005

Singh RK, Anandhan S, García-Pérez LM, Ruiz-May E, Pérez EN, Quiroz-Figueroa FR (2019) An efficient protocol for in vitro propagation of the wild legume Cicer microphyllum Benth., a crop wild relative of chickpea (Cicer arietinum L.). In Vitro Cell Developmental Biology-Plant 55:9-14. https://doi.org/10.1007/s11627-018-09958y

Singh V, Tyagi A, Chauhan PK, Kumari P, Kaushal S (2011) Identification and prevention of bacterial contamination on explant used in plant tissue culture labs. International Journal of Pharmacy and Pharmaceutical Sciences 3(4):160163

Slavin JL (2005). Dietary fiber and body weight. Nutrition 21:411-418.

Smith M, Skjøth CA, Myszkowska DAU, Puc M, Stach A, ... Brandt J (2008). Long-range transport of Ambrosia pollen to Poland. Agricultural and Forest Meteorology 148:1402-1411.

Sørensen M (1996). Yam bean (Pachyrhizus DC.). Promoting the conservation and use of underutilized and neglected crops. 2. Institute of Plant Genetics and Crop plant Research, Gatersleben/International Plant Genetic Resources Institute, Rome 
Srinivasan R, Yule S (2014). Combining bio-pesticides with chemical pesticides to manage legume pod borer (Maruca vitrata) on yard-long bean in Thailand. International Journal of Pest Management 60(1):67-72

OPEN ACCESS

(c) (i)
The journal offers free, immediate, and unrestricted access to peer-reviewed research and scholarly work. Users are allowed to read, download, copy, distribute, print, search, or link to the full texts of the articles, or use them for any other lawful purpose, without asking prior permission from the publisher or the author.

License - Articles published in Notulae Scientia Biologicae are Open-Access, distributed under the terms and conditions of the Creative Commons Attribution (CC BY 4.0) License.

(c) Articles by the authors; SHST, Cluj-Napoca, Romania. The journal allows the author(s) to hold the copyright/to retain publishing rights without restriction. 